Article

\title{
Characterization and Antioxidant Activity of Collagen, Gelatin, and the Derived Peptides from Yellowfin Tuna (Thunnus albacares) Skin
}

\author{
Mala Nurilmala ${ }^{1, *}$, Hanifah Husein Hizbullah ${ }^{1}$, Euis Karnia ${ }^{1}$, Eni Kusumaningtyas ${ }^{2}$ and \\ Yoshihiro Ochiai ${ }^{3}$ \\ 1 Department of Aquatic Product Technology, Faculty of Fisheries and Marine Science, Bogor Agricultural \\ University (IPB University), Bogor 16680, Indonesia; hhanifaa@gmail.com (H.H.H.); \\ euiskarniaa@gmail.com (E.K.) \\ 2 Indonesian Research Centre for Veterinary Science, Bogor 16114, Indonesia; enikusuma@yahoo.com \\ 3 Graduate School of Agricultural Science, Tohoku University, Sendai 980-8572, Japan; yochiai@tohoku.ac.jp \\ * Correspondence: mnurilmala@ipb.ac.id; Tel.: +62-857-7415-1345
}

Received: 9 January 2020; Accepted: 30 January 2020; Published: 31 January 2020

\begin{abstract}
Skin waste from tuna processing needs to be utilized, such as extraction of its collagen and gelatin. Their functional properties can be improved by enzymatic hydrolysis for conversion to peptides. Thus, the research objectives were to examine the characteristics and antioxidant activity of collagen, gelatin, and the derived peptide from yellowfin tuna skin. Collagen was extracted using $0.75 \mathrm{M}$ acetic acid at $4{ }^{\circ} \mathrm{C}$, while gelatin was prepared using $0.25 \%$ citric acid and extracted at $65^{\circ} \mathrm{C}$. Hydrolysis was carried out with $2 \%$ Alcalase, followed by fractionation with a molecular weight cut off sieve for both collagen and gelatin. Collagen yield was $22.6 \%$ with $\mathrm{pH}$ value of 6.63 and whiteness of $96.7 \%$. Gelatin yield was $20.0 \%$ with $\mathrm{pH}$ value of 4.94 and whiteness of $51.0 \%$. Hydrolysis for three hours resulted in $52.7 \%$ and $45.2 \%$ degree of hydrolysis for collagen and gelatin, respectively. The molecular weights of collagen peptides ranged from 2.94 to $11.93 \mathrm{kDa}$, while those of gelatin peptides ranged from 3.54 to $16,620 \mathrm{kDa}$. Antioxidant activities of these peptides were higher than those before hydrolysis. The high antioxidant activity $\left(\mathrm{IC}_{50}\right)$ of collagen peptides were found in $<3$, $3-10$, and $10-30 \mathrm{kDa}$ fractions as well as in the gelatin peptides.
\end{abstract}

Keywords: antioxidant; collagen; fractionation; gelatin; hydrolysate; tuna skin

\section{Introduction}

Tuna is one of the marine biotas that has high economical value. The global total annual catch of tuna species was around 7.5 million tons in 2018 based on The State of World Fisheries and Aquaculture by Food and Agriculture Organization (FAO) [1]. The United States of America market imported nearly 42,400 tons of fresh and frozen tuna during January to September 2016, at a value of US \$439.2 million. Among these imports, frozen tuna fillets took a 51\% share, followed by whole, dressed, and fresh/chilled tuna (43\%). Demands for frozen tuna loins in Japan have been increasing about $3 \%$ every year. Thailand, which bought $13 \%$ more cooked loins at 26,000 tons for reprocessing, is the largest importer of tuna raw material in Asia. China, Vietnam, and Indonesia are the main suppliers [2]. Fishermen of nearly 80 nations harvest tunas from the world oceans. Yellowfin tuna (Thunnus albacares) is the second most important species of tuna, which accounts for about $30 \%$ of the global catch [3]. Tunas are commonly produced for canning and freezing. Frozen products are usually in the form of whole fish or loins. The freshness and quality of tuna meat is usually evaluated based on the oxidation extent of the muscle pigment, myoglobin [4]. The frozen tuna products could leave bones and skin wastes. The proportion of tuna skin is about $5-8 \%$ of the total fish weight. Tuna bones and skins are 
generally used only to feed cattle with reduced selling price. For value addition, the skin waste from industrial tuna loins as well as fillets can be utilized as the materials for collagen and gelatin [5-7]. However, a large amount of tuna skin has remained underutilized, despite the fact that it can be an excellent source of collagen and gelatin, provided that they are demonstrated to be of high quality. The bottleneck for the utilization of tuna skin is the high fat content.

Commercial collagen and gelatin are generally produced from the skins and bones of pigs and cows. However, their usage raises religious issues, because Hinduism forbids consumption of cows, while Islam and Judaism forbid that of pigs. In addition, there are associated health concerns such as bovine spongiform encephalopathy (BSE), transmissible spongiform encephalopathy (TSE), and foot and mouth disease (FMD). Therefore, fishery by-products such as skin, bone, scale, and swim bladder could be alternatives for collagen and gelatin production [8-10]. The yellowfin tuna skin waste could be an alternative raw material for making safe and preferable collagen and gelatin.

Collagen is a connective tissue protein found in skin, teeth, and bones. Collagen can be converted to gelatin by high temperature treatment. Both collagen and gelatin-which contain glycine, proline, and hydroxyproline as the major amino acids-have significant potential as the initial substrates to produce bioactive peptides [11,12]. The biological properties of the derived peptides are largely dependent on the structure and molecular weight. Enzymatic hydrolysis is an effective method for obtaining bioactive peptides [13]. Recently, the bioactive peptide with antioxidant properties from enzymatically hydrolyzed proteins is a topic of great interest in the pharmaceutical and food processing industries [14]. Previous researchers reported that Alcalase showed the most effective among five kinds of proteases to hydrolyze gelatin from skipjack Katsuwonus pelamis scales, resulting in strong antioxidant activities of the peptides obtained [8]. Antioxidant supplementation can maintain normal skin cell function by preventing free radical accumulation [15]. Superior antioxidant activity of peptides prevents oxidative stress which is the main cause of aging. Biomolecules with strong antioxidant capacity are widely used in anti-aging research [16]. Under these backgrounds, this study aimed to investigate the characteristics of tuna skin collagen and gelatin, and the antioxidant activity of their hydrolysates.

\section{Results and Discussion}

\subsection{Physicochemical Characteristics}

Physicochemical characteristics of collagen and gelatin from yellowfin tuna are shown in Table 1. The yields of collagen and gelatin clearly show the efficiency level of the extraction process. In this study, the yield of collagen from the tuna skin was higher than those of sail fish (Istiophorus platypterus, 5.76\%) [17], ocellate puffer fish (Takifugu rubripes, 10.7\%) [18], bighead carp (Hypophthalmichthys nobilis, 17.50\%) [19], redbelly yellowtail fusilier (Caesio cuning, 18.4\%) [20], and balloonfish (Diodon holocanthus, $4 \%)$ [21]. In addition, the gelatin yield in this study (19.97\%) was quite high when compared with that of skipjack tuna (K. pelamis) skin (11.3\%) [22], emperor fish (Lethrinus sp.) skin (4.8\%) [23], and K. pelamis bone (6.37\%) [24]. The main structures of the skin inner layers and different harvesting ages could lead to differences in the yield [25].

Table 1. Characteristics of tuna skin collagen and gelatin.

\begin{tabular}{ccc}
\hline Parameter & Collagen & Gelatin \\
\hline Yield $(\%)$ & $22.63 \pm 2.04$ & $19.97 \pm 0.79$ \\
$\mathrm{pH}$ & $6.63 \pm 0.03$ & $4.94 \pm 0.01$ \\
Color & & \\
$\mathrm{L}^{*}$ (lightness) & $97.57 \pm 0.94$ & $56.46 \pm 0.78$ \\
$\mathrm{a}^{*}$ (redness) & $0.93 \pm 0.75$ & $2.56 \pm 0.55$ \\
$\mathrm{~b}^{*}$ (yellowness) & $1.21 \pm 1.17$ & $22.38 \pm 0.38$ \\
Whiteness $(\%)$ & $96.69 \pm 0.35$ & $50.97 \pm 0.72$ \\
\hline
\end{tabular}


$\mathrm{pH}$ is an important factor for the quality of collagen and gelatin. The $\mathrm{pH}$ value of tuna skin collagen preparation was 6.63, which was acceptable in accordance with Indonesian National Standard for collagen $\mathrm{pH}$ range, which is 6.5-8 [26]. The $\mathrm{pH}$ value of the gelatin was also acceptable in accordance with the Gelatin Manufacturers Institute of America standard as Type A, where the optimal pH is in the range of 3.8-5.5 for the food standard and 4.5-5.5 for the pharmaceutical one [27]. The resulting gelatin was also found to belong to Type $\mathrm{A}$, as it was prepared by an acidic process. The $\mathrm{pH}$ value is influenced by the type of material used in the pretreatment with acid or base and the neutralization step [22]. It is known that optimal $\mathrm{pH}$ value can make it easier to apply the material to the product. Neutral $\mathrm{pH}$ facilitates the interaction of proteins with water molecules, thereby improving the solubility [28].

Color does not affect the functional ability of the product. However, it remains an important factor since consumers would prefer products in brighter colors [22]. The whiteness degree of tuna collagen was $96.69 \%$, higher than those of white snapper collagen (61.33-65.41\%) [29] and skate collagen (88.4\%) [30]. In this study, it was shown that the resulting $L^{*}$ value (lightness) and whiteness of the gelatin gave lower values compared with those of the original collagen. However, the $L^{*}$ value was higher compared to that of the gelatin from giant catfish (Pangasius gigas) skin (20.43) [31]. The $\mathrm{a}^{*}$ value (redness) increased about two fold by converting the collagen to the gelatin, demonstrating that the redness was enhanced in the gelatin. On the other hand, the $b^{*}$ value (yellowness) increased nearly tenfold by the conversion, indicating that the yellowness was intensified in the gelatin. Usually, the color of commercial gelatin is pale yellow to dark amber [32]. Darker gelatin is commonly due to inorganic contaminants as well as proteins which are not removed during the extraction process. The color of gelatin is greatly dependent on fish species or the original color of fish skin, as well as conditions of extraction and drying [33].

\subsection{Molecular Size and Hydrolysis Degree}

Molecular size is an important parameter for determining the properties of collagen, gelatin, and the derived hydrolysates. Their molecular weights were estimated by sodium dodecyl sulphate-polyacrylamide gel electrophoresis (SDS-PAGE) [34,35] as shown in Figure 1.

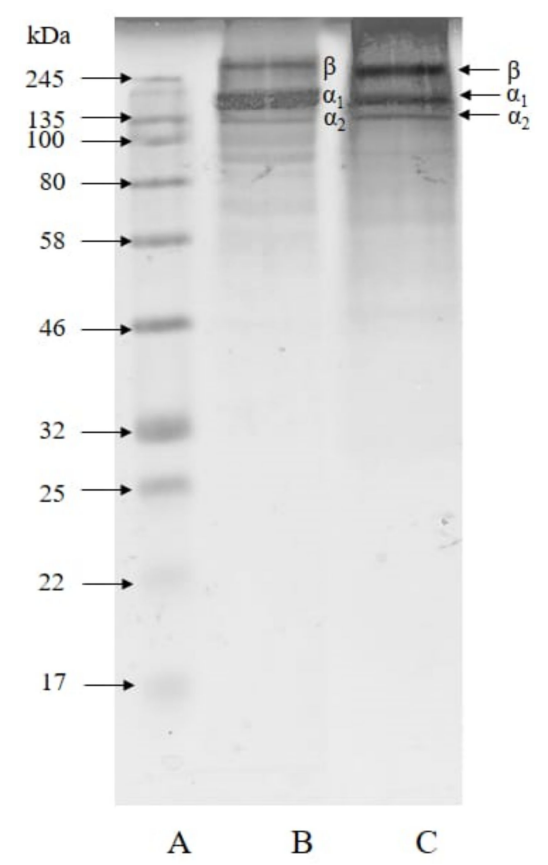

Figure 1. Sodium dodecyl sulphate-polyacrylamide gel electrophoresis (SDS-PAGE) patterns of tuna skin collagen and gelatin. A, markers; B, collagen; C, gelatin. 
The tuna skin collagen and gelatin showed similar patterns in that both consisted of $\beta, \alpha 1$, and $\alpha 2$ subunit bands. They are classified as type I collagen. The molecular weight of collagen was estimated to be $277.17 \mathrm{kDa}$. Type I collagen consists of $\alpha_{1}( \pm 120 \mathrm{kDa})$ and $\alpha_{2}( \pm 110 \mathrm{kDa})$ chains, and $\beta$ $( \pm 200 \mathrm{kDa})$ chain $[36,37]$. The molecular weight of the $\beta$ component in the gelatin was estimated to be $226.65 \mathrm{kDa}$, and those of the $\alpha_{1}$ and the $\alpha_{2}$ components were $153.85 \mathrm{kDa}$ and $134.54 \mathrm{kDa}$, respectively. Our previous study showed the yellowfin tuna skin gelatin extracted at $65^{\circ} \mathrm{C}$ consisted of $\beta$ component of $250 \mathrm{kDa}, \alpha 1$ of $129.67 \mathrm{kDa}$, and $\alpha_{2}$ of $116.36 \mathrm{kDa}$ [4]. Tuna gelatin has high molecular weight bands judging from abundant $\beta$ components [13]. The results showed that the molecular weight of yellowfin tuna skin gelatin had a similar molecular size range to that of tilapia scale gelatin Oreochromis spp. (34-260 kDa) [38].

Collagen and gelatin were then hydrolyzed with the proteolytic enzyme Alcalase at a ratio of $2 \%$ $(v / v)$ in order to obtain the hydrolysates. The hydrolysis degree (HD) of these preparations is shown in Table 2. The HD value, generally used as a parameter of proteolysis and the indicator of protein hydrolysate ratio, is the ratio of the reduced peptide bonds during hydrolysis to the total amount of the bonds in the original protein. The HD value may affect the functional properties of the hydrolysate [39]. Alcalase is a proteolytic enzyme of relatively high activity under moderate $\mathrm{pH}$ conditions compared with whose which are active at neutral and acidic $\mathrm{pH}[40]$.

Table 2. Hydrolysis degree (HD) of tuna skin collagen and gelatin by $2 \%(v / v)$ Alcalase hydrolysis for three hours.

\begin{tabular}{cc}
\hline Sample & Hydrolysis Degree (\%) \\
\hline Collagen & $52.71 \pm 1.54$ \\
Gelatin & $45.29 \pm 0.01$ \\
\hline
\end{tabular}

The molecular weight of collagen hydrolysate as estimated by SDS-PAGE was in the range of 2.94-11.93 kDa as shown in Figure 2. Generally, bioactive peptides of high antioxidant activity have a molecular size of less than $10 \mathrm{kDa}$ [41]. The gelatin hydrolysate in this study was found to fall in the range of 3.54-16.61 kDa. Guerard et al. reported that hydrolyzed gelatin prepared from tuna waste produced peptides of about 5-25 kDa [42].

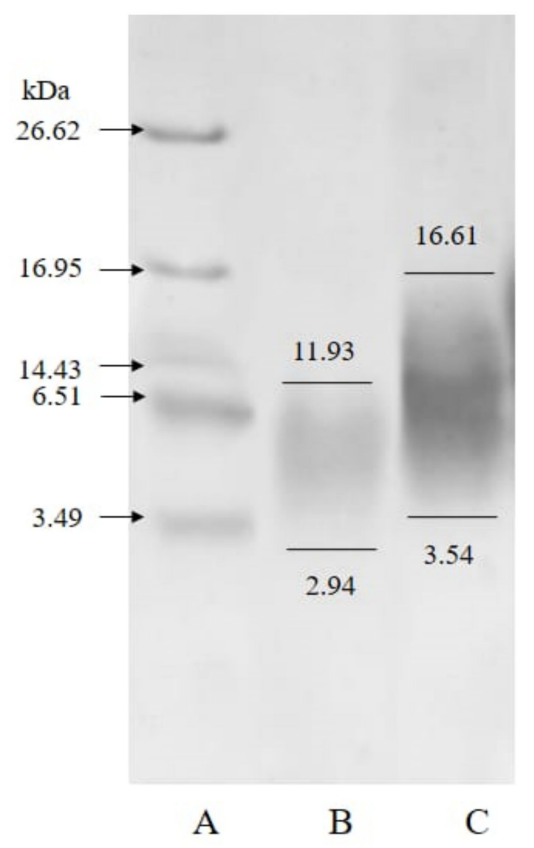

Figure 2. SDS-PAGE patterns of collagen and gelatin hydrolysate. A, markers; B, collagen hydrolysate; $\mathrm{C}$, gelatin hydrolysate. 


\subsection{Amino Acid Composition}

It is known that collagen and its thermal derivative, gelatin, are rich in amino acids such as glycine and proline. The amino acid compositions of collagen and gelatin from the yellowfin tuna skin and its hydrolysates are shown in Table 3. The composition and sequence of amino acids in gelatin depend on the species of materials, but the major ones are glycine and proline irrespective of the species so far examined [43]. The length of polypeptide chains is closely correlated with the viscosity of gelatin. The longer the polypeptide chain, the higher the gelatin viscosity value [33]. In addition, amino acid composition affects gel strength and the melting point of gelatin [44]. In addition to physical properties, amino acid composition also affects the functional properties of collagen, gelatin, and the hydrolysates, especially the antioxidant activity.

The antioxidant properties of peptides are closely related to amino acid composition, structure, and hydrophobic properties [13]. The amino acid composition of the hydrolysates was very similar to that of the parent proteins, which were rich in glycine, alanine, proline, aspartic acid, and glutamic acid. High glycine and proline contents make the antioxidant activity of fish skin gelatin higher than that of meat protein [45]. Alcalase is able to hydrolyze the bonds of aliphatic or aromatic amino acid peptides such as leucine, phenylalanine, and tyrosine [46]. Table 3 shows that the hydrolysis process lowered the amino acid levels of collagen, by maintaining the amino acid composition. The arginine content, which generally reflects the antioxidant activity, was retained through hydrolysis [47].

Table 3. Amino acid composition of tuna skin collagen, gelatin, and hydrolysates $(\mathrm{g} / 100 \mathrm{~g})$.

\begin{tabular}{ccccc}
\hline Amino Acid & Collagen & Collagen Hydrolysate & Gelatin & Gelatin Hydrolysate \\
\hline Arginine & 3.48 & 3.27 & 9.16 & 8.48 \\
Lysine & 2.24 & 1.78 & 4.21 & 4.86 \\
Threonine & 1.48 & 1.41 & 3.40 & 3.38 \\
Phenylalanine & 0.95 & 0.89 & 2.68 & 2.29 \\
Leucine & 1.13 & 1.04 & 2.68 & 2.63 \\
Valine & 0.96 & 0.96 & 2.22 & 2.27 \\
Isoleucine & 0.48 & 0.44 & 1.17 & 1.15 \\
Histidine & 0.31 & 0.29 & 0.85 & 0.72 \\
Glycine & 10.44 & 8.85 & 25.98 & 24.45 \\
Proline & 5.10 & 4.09 & 11.94 & 11.86 \\
Alanine & 5.03 & 3.64 & 10.50 & 11.20 \\
Glutamate & 5.05 & 3.34 & 10.31 & 11.61 \\
Aspartate & 2.73 & 1.93 & 5.12 & 5.83 \\
Serine & 1.53 & 1.35 & 3.78 & 3.67 \\
Tyrosine & 0.21 & 0.17 & 0.59 & 0.54 \\
\hline
\end{tabular}

\subsection{Antioxidant Activity}

The antioxidant activity was measured by a 2,2'-azino-bis (3-ethylbenzothiazoline-6-sulphonic acid) (ABTS) method as well as a 2,2-diphenyl-1-picrylhydrazyl (DPPH) method in order to examine how much the hydrolysis and fractionation process influenced the antioxidant activities. The ABTS radical is a radical with a nitrogen center that has the coloration of blue/green, when reduced by antioxidant compounds. It will turn into a non-radical form, from colored to colorless, whereas DPPH radicals are violet-colored free radicals that require electron transfer from antioxidants to transform into a colorless non-radical solution. The antioxidant activities of the collagen, gelatin, and the hydrolysates are shown in Table 4.

Antioxidants are the molecules capable of quenching reactive oxygen species as well as inhibiting the oxidation of molecules that can produce free radicals. Antioxidants are electron-donating compounds (electron donors) or reductants [48]. Antioxidant activity is associated with the progress of reductions, which have been confirmed to be terminators of chain reactions caused by free radicals [36]. Free radicals are the major factors that can accelerate glycation [49]. They can also cause oxidative stress and thus various diseases [50]. The antioxidant activities were increased through hydrolysis. 
Scavenging activity of $100 \%$ represents complete scavenging of ABTS or DPPH radicals. Hydrolysis processes could increase the scavenging activity for both ABTS and DPPH assays. As shown in Figure 3, the scavenging activities of collagen, gelatin, hydrolysate, and the fractions against ABTS were much higher compared with DPPH, as the results represent the scavenging activities against ABTS from tenfold diluted solution in the concentration range of $10-40 \mu \mathrm{g} / \mathrm{mL}$. The scavenging activities against ABTS radicals of the collagen hydrolysate from milkfish (Chanos chanos) skin showed the effectiveness at $1 \mathrm{mg} / \mathrm{mL}$ [51]. However, the scavenging activity of nearly $100 \%$ was reported for the peptide from horse milk at $1 \mu \mathrm{g} / \mathrm{mL}$ [52]. On the other hand, the gelatin hydrolysate from skipjack scale showed the scavenging activity in the concentration range of $0.1-5.0 \mathrm{mg} / \mathrm{mL}$ [8]. The lower the molecular weight, the stronger the scavenging activity tends to become. These data demonstrate that the antioxidant activities of our preparations were satisfactorily high.
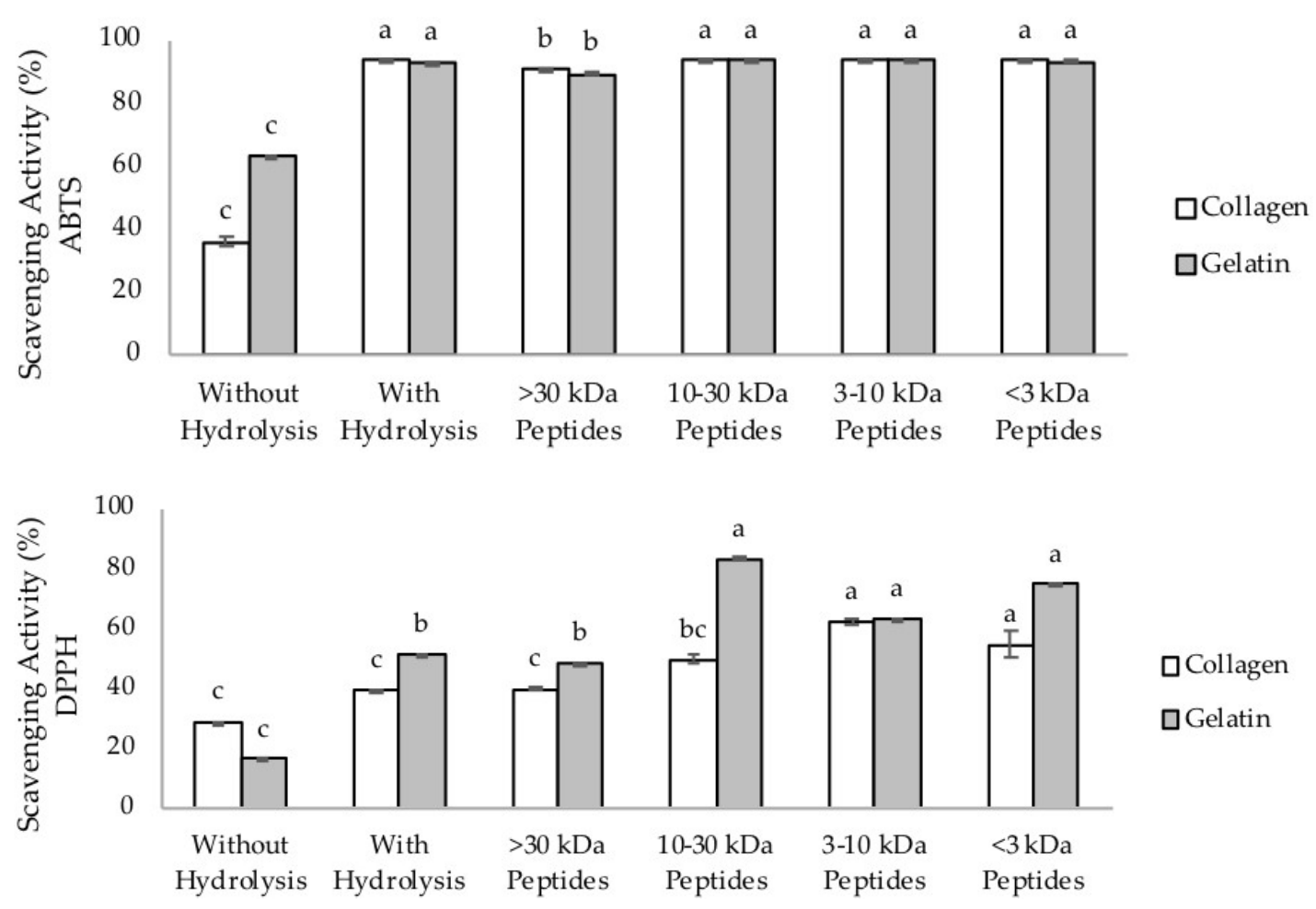

Figure 3. Scavenging activity (in percentage) of tuna skin collagen, gelatin, and hydrolysates. Upper figure, 2,2'-azino-bis (3-ethylbenzothiazoline-6-sulphonic acid (ABTS) method; lower figure, 2,2-diphenyl-1-picrylhydrazyl (DPPH) method. The different letters indicate significant differences $(p<0.05)$.

In this study, $\mathrm{IC}_{50}$ values were classified as follows: Very strong, $<0.05 \mathrm{mg} / \mathrm{mL}$; strong, $0.05-0.10 \mathrm{mg} / \mathrm{mL}$; average, $0.10-0.15 \mathrm{mg} / \mathrm{mL}$; weak, $0.15-0.20 \mathrm{mg} / \mathrm{mL}$; and very weak, $>0.20 \mathrm{mg} / \mathrm{mL}$. Lower $\mathrm{IC}_{50}$ shows higher antioxidant activity [53]. The lower molecular weight peptides tend to show higher antioxidant activities, although variable molecular weight distributions also provide striking differences in the antioxidant properties of hydrolysates [54]. The average molecular weight of protein hydrolysates is one of the most important factors determining biological activity, including the antioxidant one. High antioxidant activity is generally observed for low molecular weight and severed oligopeptides. In addition, the specificity of the protease not only affects the peptide size but also the number and sequence of amino acids in the peptides, which then also affect the antioxidant activity of the hydrolysates [55].

Both ABTS and DPPH methods showed that the highest antioxidant activity of collagen hydrolysate expressed by $\mathrm{IC}_{50}$ was obtained for the peptide fractions of 3-10 $\mathrm{kDa}$, and for the gelatin peptide fractions of 10-30 $\mathrm{kDa}$. In this study, the antioxidant activities of gelatin and its hydrolysis were higher than that of collagen. In addition, antioxidant activity of gelatin was found to be higher in 
the ABTS method. This may be due to the fact that the ABTS assay tends to detect the hydrophobic and hydrophilic compounds, while the DPPH assay is suitable for hydrophobic ones as shown in our previous report $[51,56]$. In addition, the enzyme Alcalase can produce hydrolysates with higher radical scavenging capacity and iron reducing activity compared to the other enzymes such as collagenase, trypsin, or pepsin $[13,45]$.

Table 4. Antioxidant activities of tuna skin collagen, gelatin, and their hydrolysates.

\begin{tabular}{ccc}
\hline \multirow{2}{*}{ Samples } & \multicolumn{2}{c}{ IC $_{50}(\mu$ g protein/mL) } \\
\cline { 2 - 3 } & ABTS & DPPH \\
\hline Collagen & $313.29 \pm 0.15^{\mathrm{f}}$ & $560.51 \pm 0.02^{\mathrm{g}}$ \\
Hydrolyzed collagen & $66.28 \pm 0.12^{\mathrm{e}}$ & $119.10 \pm 0.01^{\mathrm{f}}$ \\
Peptides $>30 \mathrm{kDa}$ & $64.47 \pm 0.13^{\mathrm{e}}$ & $101.77 \pm 0.01^{\mathrm{f}}$ \\
Peptides 10-30 kDa & $33.02 \pm 0.05^{\mathrm{cd}}$ & $83.22 \pm 0.01^{\mathrm{de}}$ \\
Peptides 3-10 kDa & $29.24 \pm 0.02^{\mathrm{c}}$ & $75.94 \pm 0.01^{\mathrm{d}}$ \\
Peptides <3 kDa & $35.39 \pm 0.07^{\mathrm{d}}$ & $82.12 \pm 0.02^{\mathrm{de}}$ \\
Gelatin & $62.21 \pm 0.01^{\mathrm{e}}$ & $654.62 \pm 0.03^{\mathrm{g}}$ \\
Hydrolyzed gelatin & $16.28 \pm 0.01^{\mathrm{b}}$ & $78.87 \pm 0.01^{\mathrm{d}}$ \\
Peptides $>30 \mathrm{kDa}$ & $19.17 \pm 0.01^{\mathrm{b}}$ & $84.15 \pm 0.01^{\mathrm{e}}$ \\
Peptides 10-30 kDa & $9.11 \pm 0.01^{\mathrm{a}}$ & $15.12 \pm 0.01^{\mathrm{a}}$ \\
Peptides 3-10 kDa & $17.06 \pm 0.01^{\mathrm{b}}$ & $50.04 \pm 0.01^{\mathrm{c}}$ \\
Peptides <3 kDa & $11.20 \pm 0.01^{\mathrm{ab}}$ & $23.80 \pm 0.01^{\mathrm{b}}$ \\
\hline
\end{tabular}

Note: Different superscripts in the same column show significant differences $(p<0.05)$.

All the results obtained in the present study demonstrated that excellent quality of collagen, gelatin, and their hydrolysates with high antioxidant activities can be obtained from the skin waste of the tuna processing industry. These findings will be useful for effective utilization of tuna resources. In addition, these products will be accepted to those communities where the products from livestock sources are rejected due to religious reasons.

\section{Methods}

\subsection{Preparation of Collagen}

Collagen was extracted according to the method in our previous report [6]. Pretreatment of tuna skin consisted of two steps, the removal of non-collagenous protein followed by the removal of fat. After cleaning with distilled water, the skin was cut into pieces of approximately $1 \times 1 \mathrm{~cm}$. The removal of non-collagenous protein was carried out by immersing the tuna skin 1:10 $(w / v)$ in $0.1 \mathrm{M} \mathrm{NaOH}$ aqueous solution at $4{ }^{\circ} \mathrm{C}$ for $12 \mathrm{~h}$. The $\mathrm{NaOH}$ solution was changed every $2 \mathrm{~h}$.

The washed skin was neutralized with distilled water until $\mathrm{pH}$ value reached 7 , then was immersed in 10\% 1:10 (w/v) butyl alcohol for $24 \mathrm{~h}$ for fat removal, and then neutralized with distilled water. Collagen extraction was carried out with $0.75 \mathrm{M}$ acetic acid at a ratio of $1: 10(w / v)$ at $4{ }^{\circ} \mathrm{C}$ for $72 \mathrm{~h}$. Filtration through a filter paper was carried out to collect collagen. The filtered residue was extracted with the same concentration of acetic acid for another $72 \mathrm{~h}$. Subsequently, collagen was precipitated by adding solid $\mathrm{NaCl}$ to a final concentration of $1.8 \mathrm{M}$ and subsequent addition of $0.05 \mathrm{M}$ Tris- $\mathrm{HCl}$ ( $\mathrm{pH}$ $7.5)$ at a ratio of $1: 1(v / v)$ and was allowed to stand for $24 \mathrm{~h}$. The mixture was centrifuged at $3500 \times \mathrm{g}$ at $4{ }^{\circ} \mathrm{C}$ for $1 \mathrm{~h}$. The pellet obtained by the centrifugation was dialyzed against $0.1 \mathrm{M}$ acetic acid, and further against distilled water for $24 \mathrm{~h}$. The obtained collagen was stored frozen at $-20^{\circ} \mathrm{C}$.

\subsection{Preparation of Gelatin}

Gelatin was prepared according to our previously reported method with a slight modification [7]. The extraction was carried out by soaking the cut skin (approximately $1 \times 1 \mathrm{~cm}$ ) with $0.25 \%$ citric acid for $12 \mathrm{~h}$ at a skin and citric acid ratio of $1: 4(w / v)$. Then, the skin was washed with distilled water and extracted under vigorous agitation at $65{ }^{\circ} \mathrm{C}$ for $7 \mathrm{~h}$ at a skin and distilled water ratio of $1: 1(\mathrm{w} / \mathrm{v})$, 
followed by filtration through a calico and cotton cloth. The filtrate was dried up with a vacuum evaporator at $60^{\circ} \mathrm{C}$ for $50 \mathrm{~min}$.

\subsection{Preparation of Hydrolysates}

The skin collagen and gelatin were hydrolyzed according to Chalamaiah et al. [57] with a slight modification. The collagen and gelatin solution $(6.67 \%, w / v)$ was adjusted to $\mathrm{pH} 8$ with $\mathrm{NaOH}$, and hydrolyzed with Alcalase $(2 \%, v / v)$ (Sigma-Aldrich, St. Louis, MO, USA) at $55^{\circ} \mathrm{C}$ for $3 \mathrm{~h}$. The mixture was then left at $-20^{\circ} \mathrm{C}$ for $5 \mathrm{~min}$ for enzyme inactivation. The solution was then centrifuged at $10,000 \times \mathrm{g}$ at $4{ }^{\circ} \mathrm{C}$ for $15 \mathrm{~min}$, and the supernatant was obtained as the hydrolysate.

\subsection{Fractination}

Peptides were fractionated based on their molecular sizes using a molecular weight cut-off (MWCO) membrane 30, 10, and $3 \mathrm{kDa}$ (Millipore Co. Ltd., Waltham, MA, USA) according to Kusumaningtyas et al. [54] with a slight modification. Namely, the peptide solutions were poured into $1.5 \mathrm{~mL}$ Eppendorf tubes equipped with a membrane, which were subsequently centrifuged at $5000 \times \mathrm{g}$ at $22^{\circ} \mathrm{C}$ for 10,15 , or $30 \mathrm{~min}$, respectively. The resulting fractions of $>30 \mathrm{kDa}, 10-30 \mathrm{kDa}, 3-10 \mathrm{kDa}$, and $<3 \mathrm{kDa}$ were designated as F1, F2, F3, and F4, respectively.

\subsection{Molecular Weight Estimation}

The protein profile was analyzed based on molecular weight according to Laemmli (1970) by a sodium dodecyl sulfate-polyacrylamide gel electrophoresis (SDS-PAGE) method [58]. For SDS-PAGE analysis, 3\% stacking gel and 15\% separating gel for collagen and gelatin were used, as well as $17.5 \%$ for the hydrolysates. Samples of $2 \mathrm{mg}$ were dissolved in $1 \mathrm{~mL}$ of $5 \% \mathrm{SDS}$, heated at $85{ }^{\circ} \mathrm{C}$ for $1 \mathrm{~h}$, centrifuged at $12,400 \times \mathrm{g}$ for $5 \mathrm{~min}$. After mixing $20 \mu \mathrm{L}$ each of the sample and $2 \times$ Laemmli buffer, the mixture was heated at $85{ }^{\circ} \mathrm{C}$ for $10 \mathrm{~min}$ before $15 \mu \mathrm{L}$ of which was loaded onto the gel well. Electrophoresis was carried out at $13 \mathrm{~mA}$ and $100 \mathrm{~V}$ for $3 \mathrm{~h}$. Electrophoresis was stopped when the front dye reached about $0.5 \mathrm{~cm}$ from the bottom of the gel. Gel staining was carried out using Coomassie brilliant blue, followed by destaining in $25 \%$ methanol and $10 \%$ acetic acid. The gel was scanned using Photocapt software.

\subsection{Hydrolysis Degree Analysis}

The hydrolysis degree was determined according to Baharrudin [39]. To $20 \mathrm{~mL}$ of hydrolysate was added $20 \mathrm{~mL}$ of $20 \%$ trichloroacetic acid $(w / v)$. The mixture was allowed to stand for $30 \mathrm{~min}$, and the precipitate was removed by centrifugation at $6000 \times \mathrm{g}$ for $30 \mathrm{~min}$. The resulting supernatant was analyzed for nitrogen content by a Kjeldahl method (AOAC 2005). The degree of hydrolysis (DH) was calculated using the following formula:

$$
D H(\%)=\frac{\text { Nitrogen content in the supernatant }}{\text { Nitrogen in the sample }} \times 100
$$

\subsection{Amino Acid Analysis}

Amino acid analysis was carried out according to Nollet [59]. Samples of collagen and gelatin $(0.1 \mathrm{~g})$ were dissolved in $5 \mathrm{~mL}$ of $6 \mathrm{M} \mathrm{HCl}$, vortexed, and then hydrolyzed at $110{ }^{\circ} \mathrm{C}$ for $22 \mathrm{~h}$. The hydrolyzed sample was transferred to a $50 \mathrm{~mL}$ measuring flask and set up to the boundary mark. The sample was filtered through a $0.45 \mu \mathrm{m}$ nitrocellulose filter (ThermoFischer Scientific, Waltham, MA, USA), and $500 \mu \mathrm{L}$ of the filtrate was mixed with $40 \mu \mathrm{L}$ of $\alpha$-aminobutyric acid (AABA) and $460 \mu \mathrm{L}$ of Aquabidest. To the mixture of $10 \mu \mathrm{L}$ was added $70 \mu \mathrm{L}$ of AccQ-Fluor Borate, and it was then vortexed. To the homogenate was added $20 \mu \mathrm{L}$ of fluorine reagent and it was then incubated at $55^{\circ} \mathrm{C}$ for $10 \mathrm{~min}$. The prepared samples were analyzed with the Ultra Performance Liquid Chromatography (UPLC) system (Shimadzu, Tokyo, Japan). 
The standard solution analysis was carried out by mixing $40 \mu \mathrm{L}$ of amino acid standards with an equal volume of the internal standard (AABA) and $920 \mu \mathrm{L}$ of distilled water, and then homogenized. The standard of $10 \mu \mathrm{L}$ was pipetted and mixed with $70 \mu \mathrm{L}$ AccQ-Fluor Borate, and then vortexed. To the homogenate was added $20 \mu \mathrm{L}$ of fluorine reagent and it was incubated at $55{ }^{\circ} \mathrm{C}$ for $10 \mathrm{~min}$. The prepared samples were analyzed as described above.

\subsection{Antioxidant Quantification}

The antioxidant activity was assayed according to ABTS and DPPH methods [51]. For the ABTS assay, a total of $100 \mu \mathrm{L}$ sample solution was mixed with $200 \mu \mathrm{L}$ ABTS solution in the microplate wells and placed at room temperature for $10 \mathrm{~min}$. The absorbance was measured at $405 \mathrm{~nm}$. For the DPPH assay, $0.2 \mathrm{mM}$ DPPH radical was added to $96 \%$ ethanol. DPPH solution was then measured at $540 \mathrm{~nm}$ until an absorbance of $1.1 \pm 0.05$ was obtained. To a total of $100 \mu \mathrm{L}$ sample solution was added $200 \mu \mathrm{L}$ of DPPH, which was then allowed to stand for $30 \mathrm{~min}$. The absorbance of the mixture was measured at $540 \mathrm{~nm}$. The scavenging activity of peptide fractions to ABTS and DPPH radicals was expressed using equation:

$$
\text { Scavenging activity }(\%)=\frac{(A 0-A 1)}{A 0} \times 100
$$

where

$$
\begin{aligned}
& A 0=\text { absorbance of ABTS/DPPH, and } \\
& A 1=\text { final absorbance. }
\end{aligned}
$$

Inhibition concentration of $50 \%$ free radical activity $\left(\mathrm{IC}_{50}\right)$ values were calculated using the linear regression equation. $\mathrm{IC}_{50}$ values were obtained by entering $\mathrm{y}=50$ and the known values $\mathrm{a}$ and $\mathrm{b}$. The value of $x$ as IC50 can be calculated by the following equation:

$$
y=b x+a
$$

where

$$
\begin{aligned}
& \mathrm{y}=\text { antioxidant activity, } \\
& \mathrm{x}=\text { sample concentration, } \\
& \mathrm{a}=\text { slope, } \\
& \mathrm{b}=\text { intercept. }
\end{aligned}
$$

The concentration of the sample and antioxidant activity were plotted on the $\mathrm{x}$ and $\mathrm{y}$ axes, respectively, in the linear regression equation. The linear regression equation obtained in the form of the equation $\mathrm{y}=\mathrm{bx}+\mathrm{a}$ was used to find the value of $\mathrm{IC}_{50}$ of each sample by stating a value of $\mathrm{y}$ (50) and the value of $x$ to be obtained as $\mathrm{IC}_{50}$. The $\mathrm{IC}_{50}$ value states the concentration of the sample solution needed to reduce free radicals by $50 \%$.

\subsection{Statistical Analysis}

The quantitative data of the test results were processed using Excel 2013 (Microsoft, Redmond, WA, USA), Minitab 162013 (Minitab, Sate College, PA, USA), and SPSS Statistics 222013 (IBM, Armonk, NY, USA). Data were analyzed descriptively, while the experiments were designed using completely randomized design data for antioxidant activities. Data analysis was performed with one-way analysis of variance (ANOVA) at a $95 \%$ confidence interval $(\alpha=0.05)$. The level that could affect the response was further checked using a Tukey test.

\section{Conclusions}

Collagen and gelatin could be successfully prepared from tuna skin waste, which is abundantly available from tuna processing. Both the collagen and the gelatin were found to be of high quality based on the standards for commercial use. The derived peptides from both the collagen and gelatin showed strong antioxidant activities, mainly in the ABTS assay as demonstrated by the scavenging 
activity and $\mathrm{IC}_{50}$ values. The highest antioxidant activity (lowest $\mathrm{IC}_{50}$ ) of collagen hydrolysate was obtained for the peptide fractions of 3-10 kDa and for the gelatin peptide fractions of 10-30 kDa. Those of the hydrolysates and the derived peptides of gelatin were categorized as very strong. Tuna skin waste is thus considered to be an excellent source of antioxidant peptides, making it possible to effectively utilize the waste and add value to tuna resources. Further study is now ongoing to identify the strong antioxidant components obtained by high performance liquid chromatography.

Author Contributions: M.N. conceived, designed the experiments, supervised, and wrote the manuscript. H.H.H. and E.K. (Euis Karnia) performed the experiments and analyzed the data. E.K. (Eni Kusumaningtyas) supervised and contributed to the manipulation of analytical tools. Y.O. contributed the reagents, did the final editing and proofread the manuscript. All authors have read and agreed to the published version of the manuscript.

Funding: The present study was supported by the Ministry of Research, Technology, and Higher Education through competitive funding in joint research and publication for MN grant number 1586/IT3.11/PN/2018.

Acknowledgments: The authors are indebted to Sonja Kleinertz (DAAD Long Term Lecturer in IPB University, Indonesia) for grammar correction.

Conflicts of Interest: All the authors declare no conflict of interest.

\section{References}

1. Food and Agriculture Organization: The state of world fisheries and aquaculture. Available online: www.fao.org (accessed on 20 November 2019).

2. Food and Agriculture Organization: Trends in the production of world tuna fisheries. Available online: www.fao.org (accessed on 15 November 2019).

3. Food and Agriculture Organization: Information and analysis on world fish trade. Available online: www.fao.org (accessed on 26 November 2019).

4. Nurilmala, M.; Ushio, H.; Kaneko, G.; Ochiai, Y. Assessment of commercial quality evaluation of yellowfin tuna Thunnus albacares meat based on myoglobin properties. Food Sci. Technol.Res. 2013, 19, $237-243$. [CrossRef]

5. Nurilmala, M.; Fauzi, S.; Mayasari, D.; Batubara, I. Collagen extraction from yellowfin tuna (Thunnus albacares) skin and its antioxidant activity. Jurnal Teknologi (Sci. E Eng.) 2019, 81, 141-149.

6. Nurilmala, M.; Pertiwi, R.M.; Nurhayati, T.; Fauzi, S.; Batubara, I.; Ochiai, Y. Characterization of collagen and its hydrolysate from yellowfin tuna Thunnus albacares skin and their potencies as antioxidant and antiglycation agents. Fish. Sci. 2019, 85, 591-599. [CrossRef]

7. Nurilmala, M.; Jacoeb, A.M.; Dzaky, R.A. Characteristics of yellowfin tuna skin gelatin. J. Pengolahan Hasil Perikanan Indonesia 2017, 20, 339-350. [CrossRef]

8. Qiu, Y.T.; Wang, Y.M.; Yang, X.R.; Zhao, Y.Q.; Chi, C.F.; Wang, B. Gelatin and antioxidant peptides from gelatin hydrolysate of skipjack tuna (Katsuwonus pelamis) scales: preparation, identification and activity evaluation. Mar. Drugs 2019, 17, 565. [CrossRef]

9. Aberoumand, A. Isolation and characteristics of collagen from fish waste material. World J. Fish Mar. Sci. 2010, 2, 471-474.

10. Kaewdang, O.; Benjakul, S. Effect of ethanolic extract of coconut husk on gel properties of gelatin from swim bladder of yellowfin tuna. LWT-Food Sci. Technol. 2015, 62, 955-961. [CrossRef]

11. Lee, C.H.; Singla, A.; Lee, Y. Biomedical applications of collagen. Int. J. Pharm. 2001, 221, 1-22. [CrossRef]

12. Neves, A.C.; Harnedy, P.A.; O'Keeffe, M.B.; Alashi, M.A.; Aluko, R.E.; FitzGerald, R.J. Peptide identification in a salmon gelatin hydrolysate with antihypertensive, dipeptidyl peptidase IV inhibitory and antioxidant activities. Food Res. Int. 2017, 100, 112-120. [CrossRef]

13. Alemán, A.; Giménez, B.; Montero, P.; Gómez-Guillén, M.C. Antioxidant activity of several marine skin gelatins. LWT-Food Sci. Technol. 2011, 44, 407-413. [CrossRef]

14. Giménez, B.; Alemán, A.; Montero, P.; Gómez-Gullén, M.C. Antioxidant functional properties of gelatin hydrolysates obtained from skin of sole and squid. Food Chem. 2009, 114, 976-983. [CrossRef]

15. Park, C.; Cha, H.-J.; Hong, S.H.; Kim, G.-Y.; Kim, S.; Kim, H.-S.; Kim, B.W.; Jeon, Y.-J.; Choi, Y.H. Protective effect of phloroglucinol on oxidative stress-induced DNA damage and apoptosis through activation of 
the Nrf2/HO-1 signaling pathway in HaCaT human keratinocytes. Mar. Drugs 2019, 17, 225. [CrossRef] [PubMed]

16. Sonani, R.R.; Rastogi, R.P.; Madamwar, D. Antioxidant potential of phycobiliproteins: role in anti-aging research. Biochem. Anal. Biochem. 2015, 4. [CrossRef]

17. Tamilmozhi, S.; Veeruraj, A.; Arumugam, M. Isolation and characterization of acid and pepsin-solubilized collagen from the skin of sailfish (Istiophorus platypterus). Food Res. Int. 2013, 54, 1499-1505. [CrossRef]

18. Nagai, T.; Araki, Y.; Suzuki, N. Collagen of the skin ocellate puffer fish (Takifugu rubripes). Food Chem. 2002, 78, 173-177. [CrossRef]

19. Liu, D.; Liang, L.; Regenstein, J.M.; Zhou, P. Extraction and characterization of pepsin solubilised collagen from fins, scales, skin, bones and swim bladders of bighead carp (Hypophthalmichthys nobilis). Food Chem. 2012, 133, 1441-1448. [CrossRef]

20. Astiana, I.; Nurjanah, N.; Nurhayati, T. Characterization of acid soluble collagen from redbelly yellowtail fusilier fish skin (Caesio cuning). J. Pengolahan Hasil Perikanan Indonesia 2016, 19, 79-93. [CrossRef]

21. Huang, Y.R.; Shiau, C.Y.; Chen, H.H.; Huang, B.C. Isolation and characterization of acid and pepsin solubilized collagens from the skin of ballon fish (Diodon holocanthus). Food Hydrocoll. 2011, 25, 1507-1513. [CrossRef]

22. Shyni, K.; Hema, G.S.; Ninan, G.; Mathew, S.; Joshy, C.G.; Laksmanan, P.T. Isolation and characterization of gelatin from the skins of skipjack tuna (Katsuwonus pelamis), dog shark (Scoliodon sorrakowah), and rohu (Labeo rohita). Food Hydrocoll. 2014, 39, 68-76. [CrossRef]

23. Prihardhani, D.I.; Yunianta, Y. Extraction of fish skin gelatin (Lethrinus sp.) and the application for jelly candy product. Jurnal Pangan dan Agroindustri 2016, 4, 356-366.

24. Yang, X.R.; Zhao, Y.Q.; Qiu, Y.T.; Chi, C.F.; Wang, B. Preparation and characterization of gelatin and antioxidant peptides from gelatin hydrolysate of skipjack tuna (Katsuwonus pelamis) bone stimulated by in vitro gastrointestinal digestion. Mar. Drugs 2019, 17, 78. [CrossRef] [PubMed]

25. Rawdkeun, S.; Thitipramote, N.; Benjakul, S. Preparation and functional characterisation of fish skin and comparison with commercial gelatin. J. Food Sci. Technol. 2013, 48, 1093-1102. [CrossRef]

26. National Standardization Agency of Indonesia. Indonesia National Standard about Crude Collagen from Fish Scale, SNI 8076:2014; National Standardization Agency of Indonesia: Jakarta, Indonesia, 2014.

27. GMIA. Gelatin Handbook; Gelatin Manufacturers Institute of America: New York, NY, USA, 2012.

28. Kittiphattanabawon, P.; Benjakul, S.; Sinthusamran, S.; Kishimura, H. Characteristics of collagen from the skin of clown featherback (Chitala ornate). Int. J. Food Sci. Technol. 2015, 50, 1972-1978. [CrossRef]

29. Jamilah, B.; Umi Hartina, M.R.; Mat Hashim, D.; Sazilli, A.Q. Properties of collagen from barramundi (Lates calcarifer) skin. Int. Food Res. J. 2013, 20, 835-842.

30. Shon, J.; Eo, J.-H.; Hwang, S.J.; Eun, J.-B. Effect of processing conditions on functional properties of collagen powder from skate (Raja kenojei) skins. Food Sci. Biotechnol. 2011, 20, 99-106. [CrossRef]

31. Jongjareonrak, A.; Rawdkuen, S.; Chaijan, M.; Benjakul, S.; Osako, K.; Tanaka, M. Chemical composition and characterization of skin gelatin from farmed giant catfish (Pangasius gigas). LWT-Food Sci. Technol. 2010, 43, 161-165. [CrossRef]

32. Cole, C.G.B.; Roberts, J.J. Gelatine colour measurenment. Meat Sci. 1997, 45, 23-31. [CrossRef]

33. Pranoto, Y.; Marseno, D.W.; Rahmawati, H. Characteristics of gelatins extracted from fresh and sun-dried seawater fish skins in Indonesia. Int. Food Res. J. 2011, 18, 1335-1341.

34. Westermeier, R. Electrophoresis in Practice: A Guide to Theory and Practice; John Wiley \& Sons: Hoboken, NJ, USA, 2004.

35. Roy, V.K.; Kumar, N.S.; Gurusubramanian, G. Protein-structure, properties and their separation by SDS-polyacrilamide gel electrophoresis. Sci. Vis. 2012, 12, 170-181.

36. Chi, C.F.; Cao, Z.H.; Wang, B.; Hu, F.Y.; Li, Z.R.; Zhang, B. Antioxidant and functional properties of collagen hydrolysates from Spanish mackerel skin as influenced by average molecular weight. Molecules 2014, 19, 11211-11230. [CrossRef]

37. Kittiphattanabawon, P.; Benjakul, S.; Visessanguan, W.; Shahidi, F. Isolation and characterization of collagen from the cartilages of brownbanded bamboo shark (Chiloscyllium punctatum) and blacktip shark (Carcharhinus limbatus). LWT-Food Sci. Technol. 2010, 43, 792-800. [CrossRef]

38. Mohammad, A.W.; Kumar, A.G.; Basha, R.K. Optimization of enzymatic hydrolysis of tilapia (Oreochromis spp.) scale gelatine. Int. Aquat. Res 2015, 7, 27-39. [CrossRef] 
39. Baharrudin, N.A.; Halim, N.R.A.; Sarbon, N.M. Effect of degree of hydrolysis (DH) on the functional properties and angiotensin I-converting enzyme (ACE) inhibitory activity of eel (Monopterus sp.) protein hydrolysate. Int. Food Res. J. 2016, 23, 1424-1431.

40. Ovissipour, M.; Kenari, A.A.; Motamedzadegan, A.; Nazari, R.M. Optimization of enzymatic hydrolysis of visceral waste proteins of yellowfin tuna (Thunnus albacares). Food Bioproc. Tech. 2012, 5, 696-705. [CrossRef]

41. Daliri, E.B.M.; Oh, D.H.; Lee, B.H. Bioactive peptides. Foods 2017, 6, 32. [CrossRef] [PubMed]

42. Guerard, F.; Guimas, L.; Binet, A. Production of tuna waste hydrolysates by a commercial neutral protease preparation. J. Mol. Catal. B. Enzym. 2002, 19, 489-498. [CrossRef]

43. Raja Mohd Hafidz, R.N.; Yaakob, C.M.; Amin, I.; Noorfaizan, A. Chemical and functional properties of bovine and porcine skin gelatin. Int. Food Res. J. 2011, 18, 787-791.

44. Regenstein, J.M.; Zhou, P. Collagen and gelatin from marine by-products. In Maximising the Value of Marine By-Product; Shahidi, F., Ed.; Woodhead Publishing Limited: Cambridge, UK, 2007; pp. 279-303.

45. Gómez-Guillén, M.C.; Giménez, B.; López-Caballero, M.E.; Montero, M.P. Functional and bioactive properties of collagen and gelatin from alternative sources: a review. Food Hydrocoll. 2011, 25, 1813-1827. [CrossRef]

46. Rao, M.B.; Tanksale, A.M.; Ghatge, M.S.; Deshpande, V.V. Molecular and biotechnological aspects of microbial proteases. Microbiol. Mol. Biol. Rev. 1998, 62, 597-635. [CrossRef]

47. Sweeney, P.J.; Walker, J.M. Proteinase K (EC 3.4.21.14). In Enzymes of Molecular Biology; Burrell, M.M., Ed.; Humana Press: Totowa, NJ, USA, 1993; Volume 16, pp. 305-311.

48. Rajnarayana, K.; Ajitha, M.; Gopireddy, G.; Giriprasad, V.S. Comparative antioxidant potential of some fruits and vegetables using DPPH method. Int. J. Pharm. Technol. 2011, 3, 1952-1957.

49. Ndlovu, G.; Fouche, G.; Tselanyane, M.; Cordier, W.; Steenkamp, V. In vitro determination of the anti-aging potential of four southern African medicinal plants. BMC Complem. Altern. M. 2013, 13, 304. [CrossRef]

50. Ramasamy, R.; Vannucci, S.J.; Yan, S.S.D.; Herold, K.; Yan, S.F.; Schmidt, A.M. Advanced glycation end products and RAGE: a common thread in aging, diabetes, neurodegeneration, and inflammation. Glycobiol. 2005, 15, 16R-28R. [CrossRef] [PubMed]

51. Kusumaningtyas, E.; Nurilmala, M.; Sibarani, D. Antioxidant and antifungal activities of collagen hydrolysates from skin of milkfish (Chanos chanos) hydrolyzed using various bacillus proteases. IOP Conf. Ser.: Earth Environ. Sci. 2019, 278, 012040. [CrossRef]

52. Kusumaningtyas, E.; Widiastuti, R.; Kusumaningrum, H.D.; Suhartono, M.T. Bioactivities and analysis of peptides of Sumbawa horse milk generated by Bacillus thuringiensis protease. Indonesian J. An. Vet. Sci. 2016, 21, 244-254. [CrossRef]

53. Molyneux, P. The use of the stable free radical diphenylpicryl-hydrazyl (DPPH) for estimating antioxidant activity. J. Sci. Technol. 2004, 26, 211-219.

54. Ketnawa, S.; Martinez-Alvarez, O.; Benjakul, S.; Rawdkuen, S. Gelatin hydrolysates from farmed giant catfish skin using alkaline proteases and its antioxidative function of simulated gastro-intestinal digestion. Food Chem. 2016, 192, 34-42. [CrossRef]

55. Mosquera, M.; Giménez, B.; Ramos, S.; López-Caballero, M.E.; Gómez-Guillén, M.C.; Montero, P. Antioxidant, ACE-inhibitory and antimicrobial activities of peptide fractions obtained from dried giant squid tunics. J. Aquat. Food Prod. Technol. 2015, 25, 444-455. [CrossRef]

56. Kusumaningtyas, E.; Wiastuti, R.; Kusumaningrum, H.D.; Suhartono, M.T. Antibacterial and antioxidant activities of goat milk hydrolysate generated by Bacillus Sp. E.13. Global Veterinaria 2016, 16, 105-110.

57. Chalamaiah, M.; Hemalatha, R.; Jyothirmayi, T.; Diwan, P.V.; Kumar, P.U.; Nimgulkar, C.; Kumar, B.D. Immunomodulatory effects of protein hydrolysates from rohu (Labeo rohita) egg (roe) in balb/c mice. Food Res. Int. 2014, 62, 1054-1061. [CrossRef]

58. Laemmli, U.K. Cleavage of structural proteins during assembly of head of bacteriophage T4. Nature 1970, 277, 680-685. [CrossRef] [PubMed]

59. Nollet, L.M.L. Handbook of Food Analysis: Physical Characterization and Nutrient Analysis; Marcel Dekker: London, UK, 1996.

(C) 2020 by the authors. Licensee MDPI, Basel, Switzerland. This article is an open access article distributed under the terms and conditions of the Creative Commons Attribution (CC BY) license (http://creativecommons.org/licenses/by/4.0/). 